\title{
PROFIL LIPIDA DAGING ITIK DIBERI RANSUM MENGANDUNG SEKAM PADI TERFERMENTASI DENGAN Aspergilus niger DISUPLEMENTASI DAUN UBI JALAR UNGU (Ipomoea batatas L.)
}

\author{
SUSILA T.G.O., T. G. BELAWA YADNYA, DAN N. G. K. RONI \\ Fakultas Peternakan, Universitas Udayana, Denpasar-Bali \\ e-mail: arisacicokdiah@gmail.com
}

\begin{abstract}
ABSTRAK
Penelitian ini bertujuan mempelajari pengaruh pemberian sekam padi terfermentasi dengan Aspergilus niger disuplementasi daun ubi jalar ungu terhadap profil lipida daging itik. Rancangan acak lengkap (RAL) digunakan terdiri atas ransum kontrol (A) adalah ransum tanpa sekam padi dan daun ubi jalar ungu, (B) dan(D) adalah ransum mengandung 10\% dan 20\% sekam padi, sedangkan (C) dan (E) adalah ransum yang mengandung 10\% dan 20\% sekam padi terfermentasi dengan Aspergilus niger disuplementasi dengan daun ubi jalar ungu. Setiap perlakuan diulang tiga kali. Hasil penelitian menunjukkan bahwa total kolesterol daging itik yang mendapat perlakuan B dan $\mathrm{D}$ tidak berbeda $(\mathrm{P}>0,05)$ dengan kontrol, sedangkan pada perlakuan $\mathrm{C}$ dan $\mathrm{E}$ lebih rendah $(\mathrm{P}<0,05)$ dibandingkan kontrol. HDL daging itik perlakuan $\mathrm{B}, \mathrm{C}$, dan $\mathrm{E}$ lebih tinggi $(\mathrm{P}<0,05)$ dan perlakuan $\mathrm{D}$ tidak berbeda $(\mathrm{P}>0,05)$ dengan kontrol. LDL dan trigliserida daging itik perlakuan $\mathrm{B}$ tidak berbeda $(\mathrm{P}>0,05)$ dengan kontrol. LDL pada perlakuan $\mathrm{C}$, $\mathrm{D}$ dan $\mathrm{E}$ lebih rendah $(\mathrm{P}<0,05)$ dibandingkan dengan control. Trigliserida daging perlakuan $\mathrm{C}$ dan $\mathrm{E}$ lebih rendah $(\mathrm{P}<0,05)$ dan perlakuan $\mathrm{D}$ tidak berbeda $(\mathrm{P}>0,05)$ dengan kontrol. Dapat disimpulkan bahwa pemberian ransum yang mengandung sekam padi terfermentasi dengan Aspergilus niger disuplementasi dengan daun ubi jalar ungu pada taraf 20\% memperbaiki profil lipida daging itik.
\end{abstract}

Kata kunci: itik, sekam padi, fermentasi, ubi jalar ungu, penampilan, kolesterol

\section{LIPID PROFILE OF DUCK MEAT OFFERED RATION CONTAINNING FERMENTED RICE HULL WITH ASPERGILUS NIGER SUPPLEMENTED WITH PURPLE SWEET POTATO (IPOMOEA BATATAS L.) LEAF}

\begin{abstract}
This experiment was carried out to study the effect of fermented rice hull supplemented with purple sweet potato leaf on lipid profile of duck meat. The completely randomized design (CRD) were used consisted of ration without containing rice hull and sweet potato leaf (A as control), treatment B dan D containing 10 and $20 \%$ rice hull, but $\mathrm{C}$ and $\mathrm{E}$ containing 10 and $20 \%$ fermented rice hull with Aspergilus Niger supplemented with purple sweet potato leaf. Each treatment with three replication. Results showed that total cholesterol of duck meat at B and D were not different $(\mathrm{P}>0,05)$ compared with control. Total cholesterol at $\mathrm{C}$ and $\mathrm{E}$ lower $(\mathrm{P}<0.05)$ than control. HDL at $\mathrm{B}, \mathrm{C}$ and $\mathrm{E}$ higher $(\mathrm{P}<0.05)$ than control, but, HDL at $\mathrm{D}$ was not different $(\mathrm{P}>0.05)$ compared with control. LDL and triglyceride content at $\mathrm{B}$ was not different $(\mathrm{P}>0.05)$ with controle. $\mathrm{LDL}$ at $\mathrm{C}, \mathrm{D}$ and $\mathrm{E}$ lower $(\mathrm{P}<0.05)$ than control. Trigliceride at $\mathrm{C}$ and $\mathrm{E}$ lower than control, but at $\mathrm{D}$ was not different $(\mathrm{P}>0.05)$ with control. Its can be concluded that offered ration containing fermented rice hull with Aspergilus niger supplemented with purple sweet potato leaf at level $20 \%$ improved lipid profile of duck meat.
\end{abstract}

Keyword: duck, rice hull, permentation, purple sweet potato, performance, cholesterol

\section{PENDAHULUAN}

Pakan merupakan bagian yang terpenting dalam pemeliharaan ternak itik, karena biaya yang dikeluarkan untuk pakan mencapai 60-70\% dari total biaya produksi. Pakan yang diberikan pada ternak itik haruslah seefisien mungkin agar mampu meningkatkan pendapatan peternak. Tingginya harga pakan di Indonesia disebabkan sebagian besar bahan pakan masih diimpor. Pada tahun 2014 Food and Agriculture Organisation (FAO) melaporkan Indonesia mengimpor jagung sebanyak 3,2 juta ton dan bungkil kedele sebanyak 2,3 juta ton. 
Usaha untuk mengurangi ketergantungan pada bahan pakan impor para peternak dan peneliti menjatuhkan pilihannya pada penggunaan limbah atau bahan buangan yang mempunyai nilai ekonomi rendah dan tidak berkompetisi dengan kebutuhan manusia. Salah satu limbah yang berpotensi dimanfaatkan untuk campuran pakan ternak itik adalah sekam padi. Sekam padi adalah salah satu dari limbah pertanian yang dapat dimanfaatkan sebagai bahan pakan alternatif. Sebagai pakan ternak sekam padi memilki kadar air 12,5\%, protein $3,1 \%$ bahan extrak tanpa nitrogen $29,2 \%$, serat kasar 35\%, lemak 2,7\% dan abu 17,5\% dengan kecernaan yang sangat rendah. Untuk memperbaiki kecernaan sekam padi dapat dilakukan dengan amoniasi dan biofermentasi dengan Aspergilus niger, karena Aspergilus niger dapat memproduksi enzim selulase, glukoamilase dan alpha amilase (Muchtadi et al., 1992). Enzim yang dihasilkan ini dapat mencerna senyawa komplek menjadi senyawa yang lebih sederhana sehingga mudah diserap dalam saluran pencernaan. Pemanfaatan Aspergilus niger dalam fermentasi dapat meningkatkan nilai nutrisi ransum. Guntoro et al. (2004) melaporkan bahwa fermentasi onggok dengan Aspergilus niger meningkatkan kadar protein dari 10,44\% menjadi 23,96\%. Bidura (2007) melaporkan fermentasi bungkil kelapa dengan Aspergilus niger meningkatkan kadar protein dari 31,3\% menjadi 36,3\% dan energy dari $1667 \mathrm{kkal} /$ $\mathrm{kg}$ menjadi $2479 \mathrm{kkal} / \mathrm{kg}$. Pemberian ransum dengan kecernaan dan nilai nutrisi yang lebih tinggi cendrung akan meningkatkan laju pertumbuhan yang dikuti dengan meningkatnya kandungan lemak dan kolesterol di dalam daging itik. Kondisi ini akan menjadi masalah bagi konsumen yang menginginkan daging berkualitas baik dengan kandungan lemak dan kadar kolesterol yang rendah, sehingga perlu trobosan untuk mengurangi kandungan lemak dalam daging itik. Salah satu terobosan yang dapat dilakukan adalah dengan mencampurkan daun ubi jalar ungu dalam ransum karena kandungan antosianin yang bersifat antioksidan dalam daun ubi jalar ungu (Kumalaningsih, 2008) dapat menekan pembentukan kolesterol dalam tubuh ternak.

Penelitian ini bertujuan untuk mempelajari pengaruh pemberian ransum mengandung sekam padi diamoniasi urea dan biofermentasi dengan Aspergilus niger disuplementasi degan daun ubi jalar ungu (Ipomoea batatas L) terhadap penampilan, kapasitasitas antioksidan dan kadar kolesterol daging itik fase pertumbuhan.

\section{MATERI DAN METODE}

\section{Tempat dan lama penelitian}

Penelitian lapangan dilaksanakan di desa Guwang, Kecamatan Sukawati, Kabupaten Gianyar selama 12 minggu. Uji kapasitas antioksidan ransum dilaksanakan di Lab. Analitik Universitas Udayana. Kadar kolesterol daging itik di analisis di Lab. Nutrisi Ternak Fakultas Peternakan Universitas Udayana.

\section{Itik}

Itik yang digunakan adalah itik bali jantan umur 12 minggu sebanyak 75 ekor yang diperoleh dari seorang peternak dari Desa Ketewel, Kecamatan Sukawati, Kabupaten Gianyar.

\section{Kandang dan perlengkapannya}

Penelitian ini menggunakan kandang system battery koloni berlantai dua sebanyak 15 petak, dan setiap petak kandang menpunyai ukuran panjang, lebar dan tinggi masing-masing $70 \mathrm{~cm}$. Kandang dilengkapi dengan tempat makan dan tempat air minum yang terbuat dari bambu. Kandang juga dilengkapi dengan penampung kotoran dan makanan yang jatuh, serta lampu penerangan di malam hari.

\section{Fermentasi sekam padi dengan Aspergilus niger}

Pertama sekam padi digiling halus dengan menggunakan hummer meal, kemudian diamoniasi menggunakan urea 1\% dicampur secara merata. Selanjutnya dituangi Aspergilus niger (diperoleh dari Balai Pengkajian Teknologi Pertanian (BPTP) Bali) dan dicampur secara merata dan apabila dikepal dengan tangan tidak terlepas maka siap untuk dimasukkan ke dalam karung goni untuk diperam selama satu minggu. Setelah proses fermentasi selesai, silase dikeringkan, kemudian dicampur dengan daun ubi jalar ungu. Suplementasi daun ubi jalar ungu sebanyak 1\% dari berat silase. Daun ubi jalar ungu yang disuplementasikan adalah daun yang masih segar, namun sebelum dicampur dicincang terlebih dahulu hingga halus.

\section{Ransum}

Ransum tersusun atas jagung giling, kacang kedele, bungkil kelapa, dedak padi, tepung ikan, mineral B12, garam dapur dan sekam padi. Sekam padi yang digunakan ada yang diamoniasi urea dan difermentasi dengan Aspergilus niger disuplementasi daun ubi jalar ungu dan ada sekam padi yang tanpa diolah.

Komposisi bahan penyusun ransum disajikan pada Tabel 1. Ransum dan air minum diberikan secara ad libitum.

\section{Rancangan percobaan}

Rancangan percobaan yang diguanakan adalah rancangan acak lengkap (RAL) dengan 5 (lima) perlakuan dan tiap perlakuan terdiri atas 3 (tiga) ulangan dan tiap ulangan terdiri atas 5 (lima) ekor itik 
Tabel 1. Komposisi ransum itik bali umur 13 -24 minggu

\begin{tabular}{lccccc}
\hline \multirow{2}{*}{ Komposisi } & \multicolumn{5}{c}{ Perlakuan } \\
\cline { 2 - 6 } & $\mathrm{A}$ & $\mathrm{B}$ & $\mathrm{C}$ & $\mathrm{D}$ & $\mathrm{E}$ \\
\hline Jagung kuning & 55,36 & 49,98 & 49,98 & 44,57 & 44,57 \\
Kacang kedelai & 9,37 & 12,45 & 12,45 & 13,06 & 13,06 \\
Bungkil kelapa & 11,31 & 9,82 & 9,82 & 6,85 & 6,85 \\
Tepung ikan & 10,13 & 8,10 & 8,10 & 9,68 & 9,68 \\
Dedak padi & 13,26 & 9,00 & 9,00 & 5,23 & 5,23 \\
Sekam padi tanpa & - & 10,00 & & 20,00 & - \\
fermentasi & & & & & \\
Sekam padi terfer- & - & - & 10,00 & - & 20,00 \\
mentasi disuplentasi & & & & & \\
tepung ubi jalar ungu & & & & & \\
Mineral B12 & 0,50 & 0,50 & 0,50 & 0,47 & 0,47 \\
NaCl & 0,15 & 0,15 & 0,15 & 0,14 & 0,14 \\
Total & 100 & 100 & 100 & 100 & 100 \\
\hline
\end{tabular}

Keterangan

A: ransum tanpa mengandung sekam padi; $B$ : ransum mengandung $10 \%$ sekam padi; $C$ : ransum mengandung $10 \%$ sekam padi terfermentasi dengan Aspergilus niger disuplementasi dengan tepung daun ubi jalar ungu (Ipomoea batatas L); D: ransum mengandung $20 \%$ sekam padi; E: ransum mengandung $20 \%$ sekam padi terfermentasi dengan Aspergilus niger dan disuplementasi tepung daun ubi jalar ungu (Ipomea batatas L.)

bali jantan umur 12 minggu dengan berat badan 866,6 $\pm 46, \mathrm{o}$ g/ekor. Secara keseluruhan diperlukan 75 ekor itik.

Tabel 2. Kandungan nutrisi ransum percobaan

\begin{tabular}{lrrrrrr}
\hline \multirow{2}{*}{ Energi dan nutrien } & \multicolumn{7}{c}{ Perlakuan } & \multicolumn{1}{c}{ Standar } \\
\cline { 2 - 6 } & \multicolumn{1}{c}{$\mathrm{A}$} & \multicolumn{1}{c}{$\mathrm{B}$} & \multicolumn{1}{c}{$\mathrm{C}$} & \multicolumn{1}{c}{$\mathrm{D}$} & \multicolumn{1}{c}{ NRC } \\
\hline Energi (kkal ME/kg) & 2885,6 & 2860,8 & 2867,6 & 2801 & 2804 & 2800 \\
Protein kasar (\%) & 17,22 & 17,54 & 17,78 & 17,11 & 17,12 & $15-17$ \\
Lemak (\%) & 5,34 & 6,08 & 6,08 & 5,84 & 5,85 & $4-7$ \\
Serat kasar (\%) & 6,90 & 7,76 & 7,77 & 10,32 & 10,32 & $3-6$ \\
Ca (\%) & 0,94 & 0,77 & 0,77 & 0,86 & 0.86 & 0,8 \\
P (\%) & 0,51 & 0,52 & 0,51 & 0,48 & 0,48 & 0,5 \\
\hline
\end{tabular}

\section{Peubah yang diamati}

Peubah yang diamati meliputi konsumsi ransum, pertambahan bobot badan, konversi ransum, kapasitas antioksidan ransum, kadar total kolesterol, high density lipoprotein (HDL), low density lipoprotein (LDL) dan trigliserida daging.

\section{Analisis Statistik}

Data yang diperoleh dianalisis dengan sidik ragam dan bila antar perlakuan terdapat perbedaan yang nyata $(\mathrm{P}<0,05)$, analisis dilanjutkan dengan Duncan Multiple Test (Steel dan Torrie, 1989)

\section{HASIL DAN PEMBAHASAN}

\section{Konsumsi ransum}

Konsumsi ransum pada itik yang mendapat ransum kontrol (A) selama 12 minggu adalah $7465 \mathrm{~g} /$ ekor (Tabel 2) Itik diberi ransum ransum mengandung 10\% dan 20 \% sekam padi tanpa fermentasi (perlakuan B dan D) mengkonsumsi ransum secara statistik nyata
$(\mathrm{P}<0,05)$ lebih tinggi dibandingkan dengan itik yang mendapat ransum kontrol (A), sedangkan itik yang mendapat ransum mengandung sekam padi terfermentasi disuplementasi daun ubi jalar ungu pada aras 10 dan 20 \% (Perlakuan C dan E) mengkonsumsi ransum lebih rendah $(\mathrm{P}<0,05)$ dibandingkan dengan kontrol. Konsumsi ransum terendah diperoleh pada perlakuan E yakni 7128,66 g/ekor. Lebih tingginya konsumsi ransum pada perlakuan B dan D disebabkan mengandung serat kasar yang relative lebih tinggi dibandingkan pada perlakuan A (Tabel 3). Lebih tingginya kandungan serat kasar menyebabkan laju aliran ransum dalam saluran pencernaan menjadi cepat (Bidura et al., 2008), akibatnya saluran pencernaan cepat kosong dan itik mengkonsumsi pakan lagi. sehingga konsumsi ransum menjadi lebih tinggi. Lebih rendahnya konsumsi ransum pada perlakuan $\mathrm{C}$ dan $\mathrm{E}$ diduga fermentasi sekam padi dengan Aspergilus niger meningkatkan kandungan energi, sesuai dengan pendapat Bidura et al. (2007) bahwa fermentasi bungkil kelapa dengan Aspergilus niger meningkatkan kandungan energi dari $1667 \mathrm{Kkal} /$ $\mathrm{kg}$ menjadi $2479 \mathrm{Kkal} / \mathrm{kg}$ pada gilirannya meningkatkan kandungan energi ransum, akibatnya ransum yang dikonsumsi semakin sedikit. Itik mengkonsumsi ransum untuk memenuhi kebutuhannya akan energi. Apabila kebutuhan energinya telah terpenuhi itik akan berhenti makan walaupun temboloknya masih kosong (Wahju, 2004).

Widodo (2009) dikutip Fitro et al. (2016) melaporkan konsumsi ransum dipengaruhi oleh suhu, temperature, kesehatan ternak, perkandangan, wadah pakan, kandungan zat makanan dalam ransum dan stress yang terjadi pada ternak. Konsumsi ransum juga dipengaruhi oleh besarnya ternak (Wahju, 2004), sedangkan menurut Anggorodi (1995) konsumsi ransum dipengaruhi oleh kesehatan ternak, palatabilitas, dan tata cara pemberiannya.

\section{Pertambahan bobot badan}

Pertambahan bobot badan pada itik yang mendapat perlakuan A adalah 371,66 g/ekor (Tabel 3). Pertambahan bobot badan itik yang mendapat perlakuan B dan D berbeda tidak nyata $(\mathrm{P}>0,05)$ dengan perlakuan $\mathrm{A}$, ini berarti penggunaan sekam padi tanpa fermentasi sampai pada taraf $20 \%$ tidak berpengaruh terhadap pertambahan bobot badan itik. Pertambahan bobot badan itik yang mendapat perlakuan $\mathrm{C}$ dan $\mathrm{E}$ nyata $(\mathrm{P}<0,05)$ lebih tinggi dibandingkan dibandingkan itik perlakuan A. Pertambahan bobot badan tertinggi diperoleh pada perlakuan E sebesar 551,00 g/ kor dan terendah pada perlakuan B yakni 358,66 g/ekor. Lebih tingginya pertambahan bobot badan pada itik yang mendapat perlakuan $\mathrm{C}$ dan E disebabkan fermentasi sekam padi dengan $A s-$ pergilus niger meningkatkan kecernaan (Susila et al., 
Tabel 3. Penampilan itik bali fase pertumbuhan dideri ransum mengandung sekam padi terfermentasi dengan Aspergilus niger disuplementasi daun ubi jalar ungu (Ipomea batatas L) selama 12 minggu

\begin{tabular}{|c|c|c|c|c|c|c|}
\hline \multirow{2}{*}{ Peubah } & \multicolumn{5}{|c|}{ Perlakuan $^{1)}$} & \multirow{2}{*}{$\mathrm{SEM}^{3)}$} \\
\hline & A & $\mathrm{B}$ & $\mathrm{C}$ & $\mathrm{D}$ & $E$ & \\
\hline Konsumsi ransum (g/ekor) & $7465,95 c$ & $7612,33 b$ & $7211,24 d$ & $7754,67 a$ & $7128,66 \mathrm{e}$ & 1,45 \\
\hline Kapasitas antioksidan ransum (mg/L GAEAC) & $164,34 b$ & $153,49 c$ & $191,69 a$ & $151,26 c$ & $197,06 a$ & 11.5 \\
\hline Pertambahan berat badan (g/ekor) & $371.66 c$ & $358,66 c$ & $418,00 \mathrm{~b}$ & $359,33 c$ & $551,00 a$ & 13,62 \\
\hline FCR & $20,09 a$ & $21,29 a$ & $17,28 b$ & $21,93 a$ & $12,97 \mathrm{c}$ & 0,55 \\
\hline
\end{tabular}

2015), karena Aspergilus niger mampu menghasilkan enzim selulase, glukoamilase, pectin liase dan alpha amylase yang mampu memecah senyawa komplek menjadi senyawa yang lebih sederhana, sehingga nutrien yang diserap melalui saluran pencernaan meningkat, akibatnya pertambahan bobot badan lebih tinggi.

\section{Konversi ransum}

Itik yang mendapat perlakuan A, konversi ransumnya 20,09. Konversi ransum pada itik yang mendapat perlakuan B dan D berbeda tidak nyata ( $\mathrm{P}>0,05)$ dengan konversi ransum pada itik A. Ini berarti kualitas ransum pada perlakuan B dan D tidak jauh berbeda dengan kualitas ransum pada perlakuan A. Konversi ransum pada itik yang mendapat perlakuan $\mathrm{C}$ dan $\mathrm{E}$ nyata $(\mathrm{P}<0,05)$ lebih rendah dibandingkan dengan itik A. Konversi ransum terendah 12,97 diperoleh pada perlakuan E dan tertinggi pada perlakuan B yakni sebesar 21,29. Konversi ransum merupakan imbangan antara ransum yang dikonsumsi dengan pertambahan bobot badan dalam satuan berat dan satuan waktu yang sama. Konsumsi ransum itik pada perlakuan $\mathrm{C}$ dan $\mathrm{E}$ lebih rendah dibandingkan dengan perlakuan A, namun pertambahan bobot badannya lebih tinggi dibandingkan dengan itik yang mendapat perlakuan A, akibatnya konversi ransum yang dihasilkan lebih rendah. Konversi ransum terendah diperoleh pada perlakuan E. Ini berarti efisiensi penggunaan ransum E lebih tinggi dibandingkan dengan perlakuan lainnya. James (1992) mengemukakan bahwa faktor yang memengaruhi konversi ransum adalah genetik, jenis pakan, kualitas pakan, temperatur, bahan baku zat makanan yang digunakan dalam pakan dan manajemen pemberian pakan. Bila rasio besar maka konversi ransum dianggap jelek dan jika rasio kecil maka konversi ransum dianggap bagus (Rasyaf 2008).

\section{Kapasitas Antioksidan}

Ransum perlakuan A memiliki kapasitas antioksidan 164,34 g/l GAEAC (Tabel 3). Kapasitas antioksidan pada perlakuan $B$ dan $D$ secara statistik nyata $(\mathrm{P}<0,05)$ lebih rendah, sedangkan pada perlakuan $\mathrm{C}$ dan $\mathrm{E}$ nyata $(\mathrm{P}<0,05)$ lebih tinggi dibandingkan dengan yang dari perlakuan A. Lebih tingginya kapasitas antioksidan pada ransum $\mathrm{C}$ dan $\mathrm{E}$ disebabkan mengandung daun ubi jalar ungu yang mengandung antosianin bersifat antioksidan (Ratih, 2010). Kapasitas antioksidan tertinggi diperoleh pada ransum E.

\section{Kadar Kolesterol}

Total kolesterol, high density lipoprotein (HDL), low density lipoprotein (HDL), dan trigliserida (TGA) daging itik yang mendapat perlakuan A adalah 60,$65 ; 12,97 ; 14,55$ dan $16,63 \mathrm{mg} / 100$ g daging itik (Tabel 3). Total kolesterol LDL dan TGA daging itik yang mendapat perlakuan B berbeda tidak nyata $(\mathrm{P}>0,05)$ dengan yang dari perlakuan A. Total kolesterol pada perlakuan $\mathrm{D}$ berbeda tidak nyata $(\mathrm{P}>0,05)$ dengan yang dari perlakuan A, sedangkan total kolesterol daging pada perlakuan $\mathrm{C}$ dan $\mathrm{E}$ nyata $(\mathrm{P}<\mathrm{O}, 05)$ lebih rendah dibandingkan dengan yang dari perlakuan A. Total kolesterol terkecil diperoleh pada perlakuan E. HDL daging pada perlakuan B, C dan E secara statistik nyata $(\mathrm{P}<0,05)$ lebih tinggi dibandingkan dengan yang dari perlakuan A, sedangkan HDL pada perlakuan D berbeda tidak nyata $(\mathrm{P}<0,05)$ dengan HDL pada perlakuanA. LDL pada perlakuan $\mathrm{C}, \mathrm{D}$ dan $\mathrm{E}$ nyata $(\mathrm{P}<0,05)$ lebih rendah dibandingkan dengan yang dari perlakuan $\mathrm{A}$. LDL terendah diperoleh pada perlakuan E. TGA pada perlakuan $\mathrm{D}$ berbeda tidak nyata $(\mathrm{P}>0,05)$ dengan yang dari perlakuan A, sedangkan TGA pada perlakuan $\mathrm{C}$ dan $\mathrm{E}$ nyata $(\mathrm{P}<0,05)$ lebih rendah dibandingkan dengan yang dari perlakuan A. TGA terendah diperoleh pada perlakuan E. Rendahnya total kolesterol, LDL dan TGA pada daging itik yang mendapat ransum $\mathrm{C}$ dan $\mathrm{E}$ disebabkan dalam ransumnya terdapat daun ubi jalar ungu yang mengandung antosianin yang mempunyai sifat sebagai antioksidan yang dapat mengurangi sintesis kolesterol. Menurut Argawa dan Rao (2000) penurunan kolesterol akibat adanya antioksidan dalam ransum, karena zat antioksidan menetralkan radikal bebas dan menarik lemak atau kolesterol ke gugus yang siklis, disamping itu zat antioksidan dapat menghambat kerja enzim 3 Hidroxy, 3 Methyl, Gluteryl KOA reduktase, sehingga asam mevalonat yang dihasilkan berkurang, akibatnya kolesterol yang diproduksi di hati berkurang, Hal ini yang menyebabkan kolesterol yang terdistribusi dalam darah dan daging berkurang. Hasil penelitian ini sesuai dengan hasil penelitian Yadnya (2013) yang melaporkan bahwa pemberian ransum 
Tabel 4. Kadar kolesterol daging itik yang mendapatkan ransum mengandung sekam padi terfermentasi dengan Aspergilus niger disuplementasi tepung daun ubi jalar (Ipomoea batatas L)

\begin{tabular}{|c|c|c|c|c|c|c|}
\hline \multirow{2}{*}{ Variabel } & \multicolumn{5}{|c|}{ Perlakuan ${ }^{1)}$} & \multirow{2}{*}{ SEM $^{3)}$} \\
\hline & A & B & $\mathrm{C}$ & D & $\mathrm{E}$ & \\
\hline Total kolesterol (mg/100 g) & $60,65 a^{1)}$ & $59,05 a$ & $42,15 b$ & $57,45 a$ & $41,5 b$ & 2,095 \\
\hline High density lipoprotein (HDL) (mg/100 g) & $12,97 b$ & $13,63 a$ & $13,67 a$ & $12,20 b$ & $14,06 a$ & 0,71 \\
\hline Low density lipoprotein (LDL) (mg/100 g) & $14,55 b$ & $15,83 a$ & $10,48 d$ & $13,26 c$ & $10,60 d$ & 0,097 \\
\hline Trigliserida acid (TGA) (mg/100 g) & $165,633 a$ & $155,83 a$ & $98,0 \mathrm{~b}$ & $132,75 a$ & $84,9 b$ & 16,44 \\
\hline
\end{tabular}

Keterangan :

1) Ransum kontrol (A), ransum $10 \%$ sekam padi (B), ransum $10 \%$ sekam padi terfermentasi Aspergilus niger disuplentasi daun ubi jalar ungu (C), ransum $20 \%$ sekam padi (D), ransum $20 \%$ sekam padi terfermentasi Aspergilus niger disuplementasi daun ubi jalar ungu (E)

2) Nilai dengan huruf yang berbeda berarti berbeda nyata $(P<0,05)$

3) SEM: Standard Error of the Treatment Means

yang mengandung daun ubi jalar ungu sebagai sumber antioksidan yang disuplementasi dengan Starpig dapat menurunkan total kolesterol dan LDL darah itik umur 23 minggu.

\section{SIMPULAN}

Pemberian ransum mengandung sekam padi terfermentasi dengan Aspargilus niger disuplementasi daun ubi jalar ungu (Ipomea batatas L) pada taraf 20\% memperbaiki profil lipida daging itik bali umur 24 minggu.

\section{DAFTAR PUSTAKA}

Anggorodi. 1995. Ilmu Makanan Ternak Umum, Penerbit PT Gramedia Jakarta

Argawa, I. S. dan A.V. Rao, 200o. Role of antioksidan lycopene in cancer and heart desease. J. Coll. Nutr. 19 (5): 563-9.

Bidura, I G. N. G. 2007. Aplikasi Product Bioteknology PakanTernak. Penerbit Universitas Udayana.

Bidura, I G. N. G., T. G. O. Susila, I. B. G. Partama. 2008. Limbah Pakan Ternak Aternatif dan Aplikasi Bioteknologi. Udayana Uneversity Press. Denpasar.

FAO. 2014. Faost Databased Gateway; http/ apps. fao. org/ lim 500./nph wrap.pl/ Trade. Crop livestock products\& Domain SUA \& Servlet. Diakses tanggal 27 Mei2015.

Fitro, R., I M. Mastika, dan G. A. M. K. Dewi. 2016. Performans ayam broiler diberi pakan mengandung tepung lumpur sawit tidak dan difermentasi Aspergilus niger dengan aras yang berbeda. Majalah Ilmiah Peternakan. Vol 19 No 2 Tahun 2016 p:71-76
James, R. G. 1992. Livestock and Poultry Production. 4th edition. The Avi Publishing, Co inc. Wesport Conecticut.

Kumalaningsih. 2008. Antioksidan, Superoksida Dismutase (SOD) Antioksidan Center. Com http// antioksidant centre.com. Diakses 10 Januari 2008.

Muchtadi. 1992. Enzim dalam Pangan. Depdikbud. Dikti. Pusat Antar Universitas. Pangan dan Gizi, IPB Bogor.

Rasyaf, M. 2008. Panduan Beternak Ayam Pedaging. Penerbit Swadaya. Jakarta.

Ratih. 2012. Manfaat Dibalik Ubi Jalar Ungu, Blog. Konsultasi gizi com/info/manfaat dibalik- ubi- jalar- ungu .html.

Susila T. G. O., T. G. Belawa Yadnya, dan N. G. K. Roni. 2015. Upaya Peningkatan Nilai Nutrisi Sekam Padi melalui Amoniasi urea, dan Biofermentasi dengan Aspergilus niger disuplementasi daun ubi jalar ungu terhadap Penampilan, Kapasitas Antioksidan dan kadar kolesterol daging itik fase Pertumbuhan. Laporan Penelitian. Fakultas Peternakan, Universitas Udayana.

Steel, R.G.D dan J. M. Torrie.1989. Principle and Procedures of Statistic Mc. Grow. Hill. Book Co Inc, New York London.

Wahju, J. 2004. Ilmu Nutrisi Unggas. Edisi ke-4. Universitas Gajah Mada Press. Yogyakarta.

Widodo, I. 2009. Pengaruh Penambahan Mineral Suplemen Biolife dalam Pakan terhadap Penampilan Produksi Ayam Pedaging, Skripsi. Universitas Brawijaya, Malang.

Yadnya, T. G. B, N. M. S. Sukmawati dan I W. Wirawan, 2013. Pemanfaatan Daun Ubi Jalar Ungu dalam Ransum yang Disuplementasi Starpig terhadap Kadar Kolesterol dalam Serum Darah dan Karkas Itik Bali, Makalah seminar Nasional di Fakultas Agroindustri, Universitas Mercu Buana, Yogyakarta. 9 Oktober 2013. 